\title{
Systemic infection of Kudoa lutjanus n. sp. (Myxozoa: Myxosporea) in red snapper Lutjanus erythropterus from Taiwan
}

\author{
Pei-Chi Wang ${ }^{1,2}$, Ju-ping Huang ${ }^{1}$, Ming-An Tsai ${ }^{1}$, Shu-Yun Cheng ${ }^{1}$, \\ Shin-Shyong Tsai ${ }^{1,3}$ Shi-De Chen ${ }^{1}$, Shih-Ping Chen ${ }^{4}$, Shih-Hau Chiu ${ }^{5}$, Li-Ling Liaw ${ }^{5}$, \\ Li-Teh Chang ${ }^{6}$, Shih-Chu Chen ${ }^{1,3, *}$
}

\footnotetext{
${ }^{1}$ Department of Veterinary Medicine, ${ }^{2}$ Department of Tropical Agriculture and International Cooperation, and

${ }^{3}$ Graduate Institute of Animal Vaccine Technology, National Pingtung University of Science and Technology, Pingtung 912, Taiwan, ROC

${ }^{4}$ Division of Animal Medicine, Animal Technology Institute Taiwan 300, Taiwan, ROC

${ }^{5}$ Bioresource Collection and Research Center, Food Industry Research and Development Institute, Hsinchu 300, Taiwan, ROC ${ }^{6}$ Basic Science, Department of Nursing, Meiho institute of Technology, Pingtung 912, Taiwan, ROC
}

\begin{abstract}
A new species of Kudoa lutjanus n. sp. (Myxosporea) is described from the brain and internal organs of cultured red snapper Lutjanus erythropterus from Taiwan. The fish, 260 to $390 \mathrm{~g}$ in weight, exhibited anorexia and poor appetite and swam in the surface water during outbreaks. Cumulative mortality was about $1 \%$ during a period of $3 \mathrm{wk}$. The red snapper exhibited numerous creamy-white pseudocysts, 0.003 to $0.65 \mathrm{~cm}(\mathrm{n}=100)$ in diameter, in the eye, swim bladder, muscle and other internal organs, but especially in the brain. The number of pseudocysts per infected fish was not correlated with fish size or condition. Mature spores were quadrate in apical view and suboval in side view, measuring $8.2 \pm 0.59 \mu \mathrm{m}$ in width and $7.3 \pm 0.53 \mu \mathrm{m}$ in length. The 4 valves were equal in size, each with 1 polar capsule. Polar capsules were pyriform in shape, measuring $3.62 \pm 0.49 \mu \mathrm{m}$ in length and $2.2 \pm 0.49 \mu \mathrm{m}$ in width. Mild inflammatory responses or liquefaction of host tissue were associated with $K$. lutjanus $\mathrm{n}$. sp. infection. The junction of shell valves appeared as overlapping, straight lines. The polar filament formed 2 to 3 coils. A general PCR (polymerase chain reaction) primer for Kudoa amplified the small subunit (SSU) rDNA sequences, and the amplified gene was sequenced. It was evident from the phylogenetic tree that the 3 strains tested, AOD93020M, AOD93028M and AOD93028B, were identical and belonged to the Kudoa SS rRNA subgroup. The evolutionary tree showed that these strains form a unique clade, at a distance from other Kudoa species and myxosporeans. The spore's morphological and ultrastructural characteristics, as well as the SS rDNA properties of the isolates, were also essentially identical and served to distinguish them from representative Kudoa. It is, therefore, proposed that the strains isolated from the diseased red snapper be assigned to a new species.
\end{abstract}

KEY WORDS: Myxosporea $\cdot$ Kudoa lutjanus n. sp. Brain $\cdot$ Red snapper $\cdot$ Lutjanus erythropterus Resale or republication not permitted without written consent of the publisher

\section{INTRODUCTION}

Myxosporeans of the genus Kudoa frequently infect the somatic musculature of marine and estuarine fishes (Kudo 1966). These parasites develop white pseudocysts or trigger widespread infection inside muscle fibers; numerous myxosporean species have been linked with muscle fiber. Many species have also been connected with post mortem liquefaction of muscle tissue, ordinarily referred to as soft-flesh disease (Patashnik \& Groninger 1964, Langdon 1991). Most Kudoa spp. infect the somatic muscle of their fish host. Species of the genus Kudoa Meglitsch, 1947 are myxosporean parasites with 4 valves, each containing 
a polar capsule (Hervio et al. 1997, Moran et al. 1999a, Pampoulie et al. 1999, Swearer \& Robertson 1999, Whipps et al. 2004). Most Kudoa species appear in the skeletal musculature and have been connected with post mortem myoliquefaction in commercially valuable marine fishes (Moran et al. 1999a). Kudoa thyrsites Gilchrist, 1924 has been recorded from 27 fish species dispersed worldwide (Whitaker et al. 1994). For example, this parasite has both a worldwide distribution and a wide host range (Kabata \& Whitaker 1989, Kent et al. 1994, Moran \& Kent 1999, Moran et al. 1999b). K. thyrsites does not normally cause mortality, although 1 case of high mortality in farmed Atlantic salmon Salmon salar L. has been observed (Harrell \& Scott 1985). The few remaining Kudoa species have been identified from tissues including the gills, brain, gallbladder, pericardial cavity and ovary (Lom \& Dyková 1992, Swearer \& Robertson 1999). Four species, including 1 previously unrecorded species, $K$. cerebralis, K. paralichthys n. sp., K. tetraspora and Kudoa sp., have been identified in the brain of marine and brackish fishes (Paperna \& Zwerner 1974, Narasimhamurti \& Kalavati 1979, Langdon 1990, Cho \& Kim 2003). In the present study, a new species of Kudoa was found in the brain and internal organs of cultured red snapper Lutjanus erythropterus. The authors have described its spore morphology, ultrastructural features and the polymerase chain reaction (PCR) sequencing of its small-subunit ribosomal DNA, and have carried out phylogenetic analysis.

\section{MATERIALS AND METHODS}

History, clinical signs and examination of pseudocysts. Two fish farms in south Taiwan stocked 48000 ( $5 \pm 2$ g, Fish Farm A) and 55000 ( $5 \pm 2$ g, Fish Farm B) red snapper on 16 April 2003, respectively. These fish developed anorexia and poor appetite, and a school of these fish appeared in the surface layers of the pond water on 22 December 2003, when they had reached 260 to $390 \mathrm{~g}$ in weight. Approximately 10 fish died each day from 22 December 2003 to 10 January 2004. The accumulated mortality was $1.0 \%(500 / 48000)$ at Farm A and 1.1\% (650/55 000) at Farm B within $21 \mathrm{~d}$. Ten fish were sampled for this study from 24 December 2003. After anesthesia by MS 222 (0.008\% solution), blood was taken by cardiac puncture with heparinized plastic syringes. Blood smears were stained according to the Diff-Quick method. Pseudocysts and squash preparations of fresh pseudocysts from brain and internal organs were examined by light microscope with an ocular meter. Descriptions and measurements of spores were carried out according to the guidelines for species descriptions and by using a light microscope equipped with an ocular micrometer. Mean values and standard deviations of each spore characteristic were obtained from 100 fresh, mature spores. Spores of Kudoa lutjanus n. sp. were collected directly from pseudocysts in the brain and somatic muscle tissue.

Bacteriology. Swabs were taken from the brain, kidney, spleen and liver and streaked onto tryptic soy agar (TSA), TSA with $5 \%$ goat blood (blood agar, BA), brain-heart infusion agar, Sabouraud's dextrose agar and Lowenstein-Jensen medium. Plates were then incubated at $25^{\circ} \mathrm{C}$ for $21 \mathrm{~d}$.

Pathology. The brain, eye, gills, kidney, heart, liver, spleen and other internal organs with lesions were fixed in $10 \%$ buffered formalin and processed for paraffin sectioning. The sections were stained with hematoxylin and eosin (H\&E).

Electron microscopy. The pseudocysts from brain and internal organs were fixed with $2.5 \%$ glutaraldehyde in $0.2 \mathrm{M}$ sodium cacodylate for transmission electron microscopy and post-fixed in $1 \%$ osmium tetroxide in $0.2 \mathrm{M}$ sodium cacodylate. Sections were stained in uranyl acetate and lead citrate before examination.

Extraction of DNA. Pseudocysts from infected red snapper were collected and homogenized in phosphate-buffered saline (PBS, $\mathrm{pH}$ 7.2). The pelleted spores were then lysed with lysozyme at $30 \mathrm{mg} \mathrm{ml}^{-1}$ for $1 \mathrm{~h}$ at $37^{\circ} \mathrm{C}$, followed by addition of SDS to $5 \%(\mathrm{w} / \mathrm{v})$ for $15 \mathrm{~min}$ at $37^{\circ} \mathrm{C}$. Equal volumes of phenol/chloroform/ isoamylalcohol $(25: 24: 1)$ solution were added to the lysate and gently mixed before centrifugation at $12000 \times g$ for $15 \mathrm{~min}$ at $4^{\circ} \mathrm{C}$. The supernatant layer was then collected, and DNA was precipitated by addition of $0.5 \mathrm{vol}$ of isopropanol and incubation for $30 \mathrm{~min}$ at $-20^{\circ} \mathrm{C}$, followed by centrifugation at $12000 \times g$ for $15 \mathrm{~min}$ at $4^{\circ} \mathrm{C}$. The DNA pellet was washed with $70 \%$ ethanol, dried in a speedvac and then resuspended in $20 \mu \mathrm{l}$ of TE buffer.

DNA amplification and sequencing. The sequences of specific PCR primers for identification of the Kudoa genus were obtained from Hervio et al. (1997) and comprised KUD1f (5-CTATCAACTAGTTGGTGA-3) and KUD2r (5-CAATATCTGGACCTGGTG-3). These primers targeted a region of the small subunit (SSU) rDNA from $K$. amamiensis, $K$. miniauriculata and $K$. paniformis and produced a $890 \mathrm{bp}$ amplicon. Typical PCRs were carried out in a final volume of $50 \mu \mathrm{l}$, containing $1.25 \mathrm{U}$ of recombinant Taq DNA polymerase (Takara) per $50 \mu \mathrm{l}, 1 \times$ buffer (Takara), nucleotides $\left(0.25 \mathrm{mM} \mathrm{l}^{-1}\right.$ final concentration for each nucleotide) and primer $(0.5 \mu \mathrm{M})$. The DNA $(5 \mu \mathrm{l})$

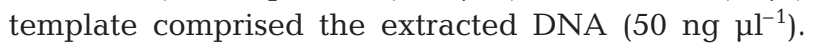
Amplification conditions consisted of an initial denaturation step at $95^{\circ} \mathrm{C}$ for $3 \mathrm{~min}$, followed by 35 cycles of 
denaturation at $94^{\circ} \mathrm{C}$ for $1 \mathrm{~min}$, annealing at $53^{\circ} \mathrm{C}$ for $1 \mathrm{~min}$ and extension at $72^{\circ} \mathrm{C}$ for 2 min, except for the last cycle in which the extension step was for $10 \mathrm{~min}$. PCR products (5 $\mathrm{kl}$ ) were subjected to electrophoresis (35 min, $100 \mathrm{~V}$ ) in $2 \%$ agarose gel (SeaKem LE agarose) with $1 \times$ TBE buffer (BDH Laboratory Supplies) containing $90 \mathrm{mM}$ Tris, $90 \mathrm{mM}$ borate and 2 mM EDTA (pH 8.3), and were visualized by UV transillumination with ethidium-bromide staining. The DNA molecular-weight marker comprised a 100 bp DNA ladder [100-bp (electrophoretic types) ET marker, Chenig Hsin Tang Chemical].

SSU rDNA sequencing. Direct sequencing of the SSU rDNA sequence of Strains AOD93020M, AOD93028B and AOD93028M was carried out using a Taq DyeDeoxy Terminator Cycle Sequencing Kit and a 373A DNA Sequencer (Applied Biosystems). The resultant SSU rDNA sequence was aligned manually against sequences of representative Kudoa strains; the additional sequence data were retrieved from the GenBank database. Using CLUSTAL X software, Version 1.81, phylogenetic trees were inferred with the minimum-evolution (Rzhetsky \& Nei 1993), maximum-parsimony (Fitch 1972) and neighbor-joining (Saitou \& Nei 1987) treeing algorithms. Evolutionary-distance matrices for the minimum-evolution, maximum-parsimony and neighbor-joining methods were generated according to Jukes \& Cantor (1969). MEGA2 (Kumar et al. 2001) was used for all analyses. The resultant unrooted tree topologies were evaluated in the bootstrap analyses (Felsenstein 1985) of the neighbor-joining method, based on 1000 resamplings.

\section{RESULTS}

\section{Gross pathology and bacteriology}

The diseased cultured red snapper Lutjanus erythropterus displayed many soft, spherical to ovoid pseudocysts. Pseudocysts, creamy white in color and 0.003 to $0.65 \mathrm{~cm}(\mathrm{n}=100)$ in diameter, were noted throughout the body, including the brain, eye, swim bladder, muscle (Figs. 1 to 4), serosal surface and internal organs, but they were particularly numerous in the brain, as shown in Table 1. In most fish, aggregated
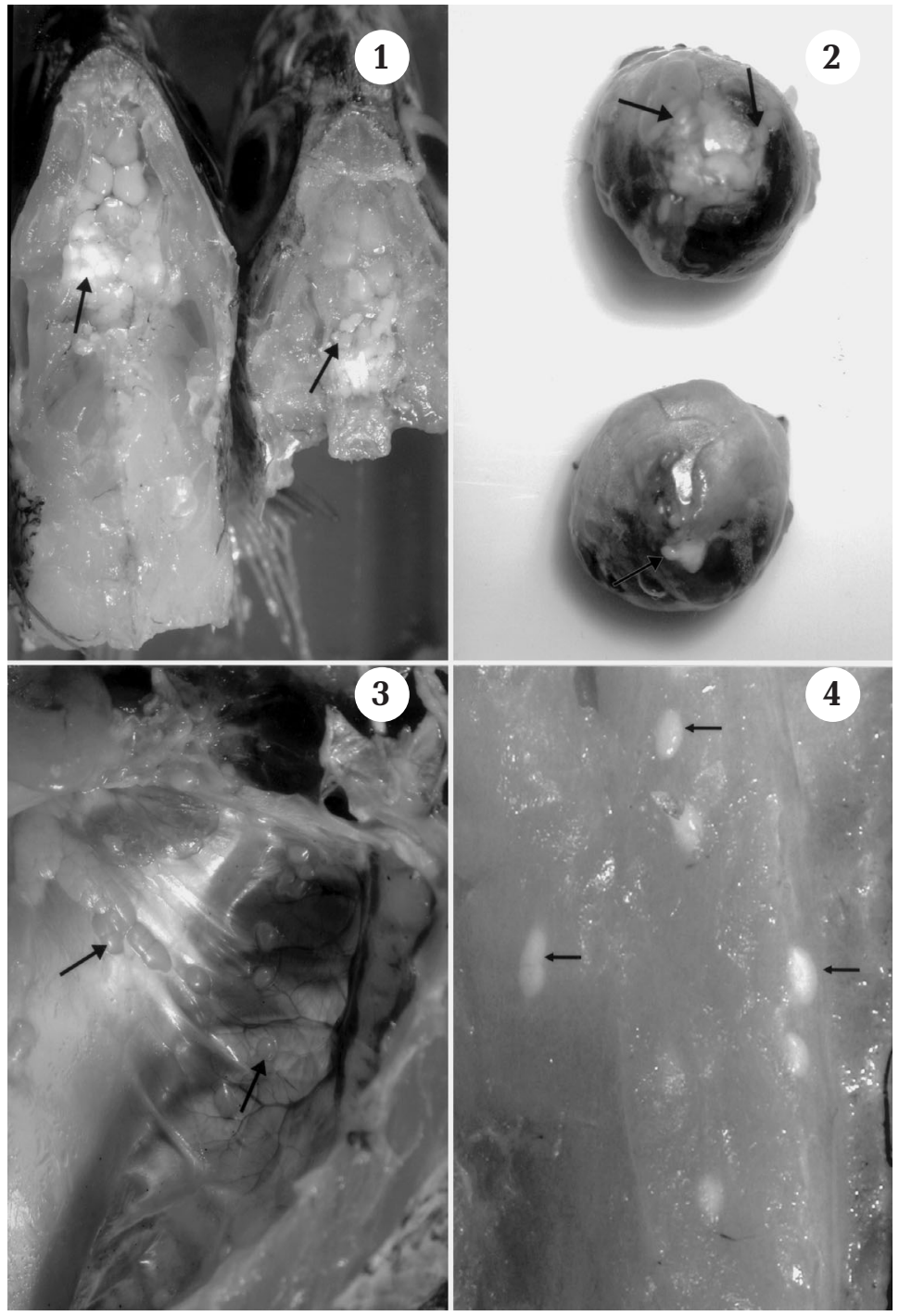

Figs. 1 to 4. Lutjanus erythropterus. Fig. 1. Red snapper brain with Kudoa infection. Numerous aggregated pseudocysts (arrows) showing on the surface of the brain are a creamy-white color. Fig. 2. Red snapper eye with Kudoa infection. Aggregated pseudocysts (arrows) showing on the eyes are a creamy-white color. Fig. 3. Red snapper swim bladder with Kudoa infection. Single pseudocyst (right arrow) and aggregated pseudocysts (left arrow) showing on the swim bladder are a creamy-white color. Fig. 4. Red snapper muscle with Kudoa infection. Pseudocysts (arrows) showing in the muscle are a creamy-white color pseudocysts appeared in the brain, eye and swim bladder (Figs. 1 to 3), but not in the muscle. The presence and density of the pseudocyst lesions in diverse organs of the red snapper are presented in Table 1. Although the intensity (mean: 180, range: 2 to 839 , $\mathrm{n}=10$ ) of pseudocysts was greatest in the brain of red snapper, the diameters of pseudocysts were smaller in the brain than in other organs (i.e. eye, swim bladder, muscle, etc). The quantity of pseudocysts per infected fish did not relate to fish size or condition. 
Table 1. Intensity of Kudoa lutjanus n. sp. pseudocysts in red snapper Lutjanus erythropterus ( $\mathrm{n}=10$ fish sampled)

\begin{tabular}{|lccccc|} 
& Brain & Eye & Muscle & $\begin{array}{c}\text { Internal } \\
\text { organs }\end{array}$ & Total \\
\hline Mean & 180 & 11 & 30 & 38 & 271 \\
Range & $2-839$ & $0-85$ & $0-159$ & $3-159$ & $6-885$ \\
\hline
\end{tabular}

\section{Spore characteristics of Kudoa lutjanus n. sp.}

Mature spores (Figs. 5 \& 6) were quadrate with shallow constrictions between the valves in the apical view and approximately suboval (Figs. 5 \& 6) in the lateral view, measuring $7.26 \pm 0.53 \mu \mathrm{m}$ in length and $8.2 \pm$ $0.59 \mu \mathrm{m}$ in width (Table 2 ). The 4 valves were equal in size, each with 1 polar capsule, each measuring $3.62 \pm$ $0.49 \mu \mathrm{m}$ in length and $2.2 \pm 0.49 \mu \mathrm{m}$ (Table 2 ) in width and enclosing a polar filament.

\section{Bacteriology}

No bacteria were discovered on tryptic soy agar, blood agar, brain-heart infusion agar, Sabouraud's dextrose agar, or Lowenstein-Jensen medium incubated at $25^{\circ} \mathrm{C}$ for $21 \mathrm{~d}$.

\section{Histopathology}

Tissue sections of cultured red snapper Lutjanus erythropterus infected with Kudoa lutjanus n. sp. (Myxozoa: Myxosporea) indicated 2 types of pseudocysts. In one type, the parasites and host tissue were divided by a thin hyaline wall without inflammatory reaction (Fig. 7). In the other type, the wall was encapsulated by fibrous tissue, and free spores were entrapped in this fibroblastic matrix. The latter type of pseudocysts frequently appeared in aggregates. Some of infected fish displayed pressed atrophy of muscle and brain (Figs. 8 \& 9). Mature spores were quadrate in apical view and suboval in side view (Fig. 10). Spores grown in the pseudocyst at the brain's surface had undergone pressure atrophy following a period of pseudocyst growth. Some pseudocysts with parasites in the internervous tissues triggered degeneration and spore release and also caused an inflammatory reaction (Fig. 9). In some cases, the lesions were found deep within the musculature and swim bladder, but they remained detectable through the muscles and epithelium.

Specific details were as follows: host: red snapper Lutjanus erythropterus; locality: Pingtung, South Taiwan, ROC infection site: brain, optic lobes, eye,

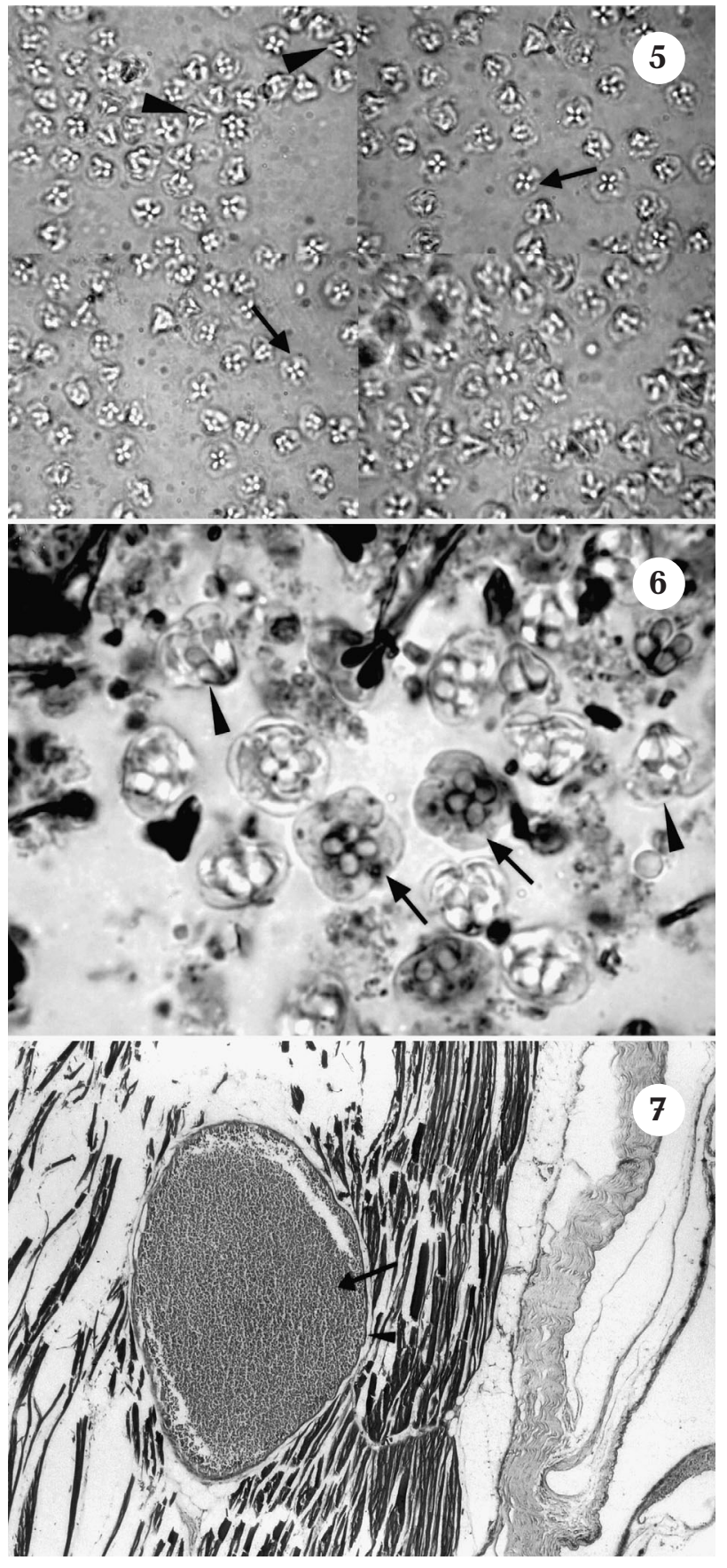

Figs. 5 to 7. Lutjanus erythropterus infected by Kudoa-type Myxosporidia. Fig. 5. Spores from red snapper brain tissues observed under an optical microscope, showing the typical arrangement of polar capsules of Kudoa-type Myxosporidia. Mature spores are quadrate (arrows) in apical view and suboval (arrowheads) in side view $(\times 1000)$. Fig. 6. Magnification of Fig. 5. Spores showing the typical arrangement of polar capsules of Kudoa-type Myxosporidia. Mature spores are quadrate (arrows) in apical view and suboval (arrowheads) in side view $(\times 2000)$. Fig. 7. Muscle of red snapper. Spores (arrow) in the pseudocyst (arrowhead) present between muscle myomeres. Fragmentation of muscle fibers appears around the pseudocyst $(\mathrm{H} \& \mathrm{E}, \times 200)$ 
muscle and internal organs; material deposited: Laboratory of Zoology, Department of Veterinary Medicine, National Pingtung University of Science and Technology, Pingtung, Taiwan, ROC, spore in $10 \%$ formalin as syntypes and pseudocysts in the host tissue in $10 \%$ formalin as voucher specimens, Accession Numbers AOD93020 and AOD93028; etymology: the specific name refers to the genus name of the host.

\section{Electron microscopy}

Transmission electron microscopy (TEM) indicated the junction of shell valves was overlapping and straight, the capsule enclosed electron-dense materials within which lay the inverted polar filament coil with 2 to 3 turns; lines were at an oblique angle within each polar capsule (Fig. 11). TEM indicated that apical projections of the spore were found (Fig. 12). The apical part of the Kudoa spore contained the 4 capsulogenic cells, each of which comprised an outer electrondense layer (0.04 to $0.07 \mu \mathrm{m}$ thick) and an inner electron-lucent layer (0.13 to $0.22 \mu \mathrm{m}$ thick). A single sporoplasm, containing 2 unequally sized nuclei, filled the posterior portion of the spore and partly enclosed the polar capsules (Fig. 13). The junctions of shell valves between the 4 valvogenic cells are overlapping and nearly straight in both longitudinal and crosssectioned specimens (Fig. 13). The junction patterns for the 4 shell valves are different among $S_{1}, S_{2}$ and $S_{3}$ spores (Fig. 13).

\section{Polymerase chain reaction}

PCR assays with DNA extracts of AOD93020M, AOD93028M and AOD93028B resulted in the amplification of an expected size of roughly $890 \mathrm{bp}$ (Fig. 14). The primers KUR1f and KUD2f generated a Kudoaspecific product, with an expected size of approximately 890 bp, failing to amplify host DNA (data not shown). Diagnostic tools to identify the Kudoa genus in infected tissue amplified a 890-bp DNA fragment from red snapper tissue containing pseudocysts. A similar fragment was amplified from 10 of the 10 fish.

\section{Phylogenetic analysis}

A PCR product for the SSU region of the rDNA gene of the 3 Kudoa strains from cultured red snapper, Lutjanus erythropterus, have been deposited in GenBank (Accession Numbers: AY644702, AY644703 and AY644704). The sequences of 3 Kudoa strains of pseudocysts from cultured red snapper are 100\% identical. Using the CLUSTAL X software, Version 1.81, the evolutionary tree (Fig. 15) shows that these strains form a unique clade, at a distance from other Kudoa and myxosporeans. This relationship was

Table 2. Kudoa spp. Comparisons of morphological characteristics of Kudoa species infecting the brain tissue of fish hosts. Mean measurements in micrometers; range in parentheses (PC: polar capsule)

\begin{tabular}{|c|c|c|c|c|c|}
\hline Species & K. cerebralis & K. tetraspora & Kudoa sp. & K. paralichthys & K. lutjanus n. sp. \\
\hline Host & $\begin{array}{l}\text { Morone } \\
\text { saxatilis }\end{array}$ & $\begin{array}{l}\text { Mugil } \\
\text { cephalus }\end{array}$ & $\begin{array}{l}\text { Lates } \\
\text { calcarifer }\end{array}$ & $\begin{array}{l}\text { Paralichthys } \\
\text { olivaceus }\end{array}$ & $\begin{array}{l}\text { Lutjanus } \\
\text { erythropterus }\end{array}$ \\
\hline Infection site & $\begin{array}{l}\text { Brain } \\
\text { lobes }\end{array}$ & Brain, optic & Brain & Brain & $\begin{array}{l}\text { Brain, optic lobes eye, } \\
\text { muscle, internal organs }\end{array}$ \\
\hline Locality & $\begin{array}{c}\text { Chesapeake } \\
\text { Bay, USA }\end{array}$ & India & $\begin{array}{c}\text { North } \\
\text { Queensland, } \\
\text { Australia }\end{array}$ & $\begin{array}{c}\text { Namhae, } \\
\text { South Korea }\end{array}$ & $\begin{array}{l}\text { Pingtung, } \\
\text { South Taiwan }\end{array}$ \\
\hline $\begin{array}{l}\text { Spore shape } \\
\text { in apical view }\end{array}$ & Quadrate & Quadrate & Quadrate & Quadrate & Quadrate \\
\hline Spore length & $5.5(4.8-5.8)$ & & $6.5-7.0$ & $5.19(4.49-5.79)$ & $7.3(6.3-7.9)$ \\
\hline Spore width & $7.0(4.8-8.6)$ & 9.0 & $9.0-10.0$ & $8.32(7.4-8.89)$ & $8.2(7.4-9.2)$ \\
\hline PC shape & Pyriform & Elongate & Pyriform & Pyriform & Pyriform \\
\hline PC width & $5.5(4.8-5.80)$ & 3.6 & $3.1-3.2$ & $2.2(1.87-2.74)$ & $3.6(3.0-4.2)$ \\
\hline PC length & $5.5(4.8-5.80)$ & 2.0 & $2.0-2.3$ & $1.2(1-1.42)$ & $2.2(1.5-2.6)$ \\
\hline Valve extensions & Absent & Absent & Absent & Absent & Absent \\
\hline $\begin{array}{l}\text { Suture of } \\
\text { shell valve }\end{array}$ & & & & L-shaped & $\begin{array}{c}\text { Overlapping, nearly } \\
\text { straight }\end{array}$ \\
\hline Source & $\begin{array}{c}\text { Paperna \& } \\
\text { Zwerner (1974) }\end{array}$ & $\begin{array}{c}\text { Narasimhamurti \& } \\
\text { Kalavati (1979) }\end{array}$ & $\begin{array}{l}\text { Langdon } \\
(1990)\end{array}$ & $\begin{array}{c}\text { Cho \& } \\
\text { Kim (2003) }\end{array}$ & Present study \\
\hline
\end{tabular}




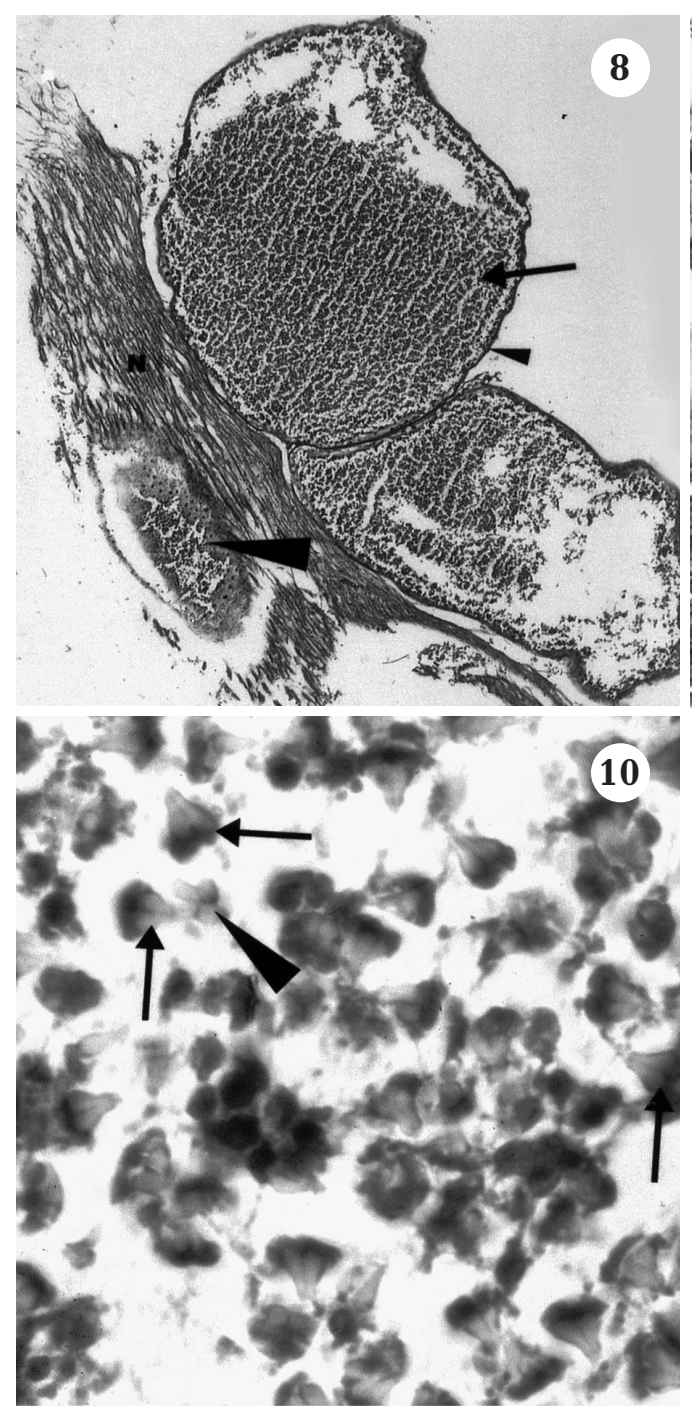

emphasized by the relatively high nucleotide similarity value and the high bootstrap-support value based on the neighbor-joining, maximum-parsimony and minimum-evolution methods.

\section{DISCUSSION}

The initial host inflammatory response to the developing stages of the myxosporean presently under consideration is generally negligible; only in later stages is there any substantial reaction. Different species of the genus Kudoa have a notable economic impact on fish muscle. Some authors claim that the parasites release myolytic enzymes upon the death of the fish, resulting in rapid liquefaction. In this study, numerous creamy-white, single pseudocysts appeared on the serosal surface, in the swim bladder, mesentery and internal organs, and especially in the brain.

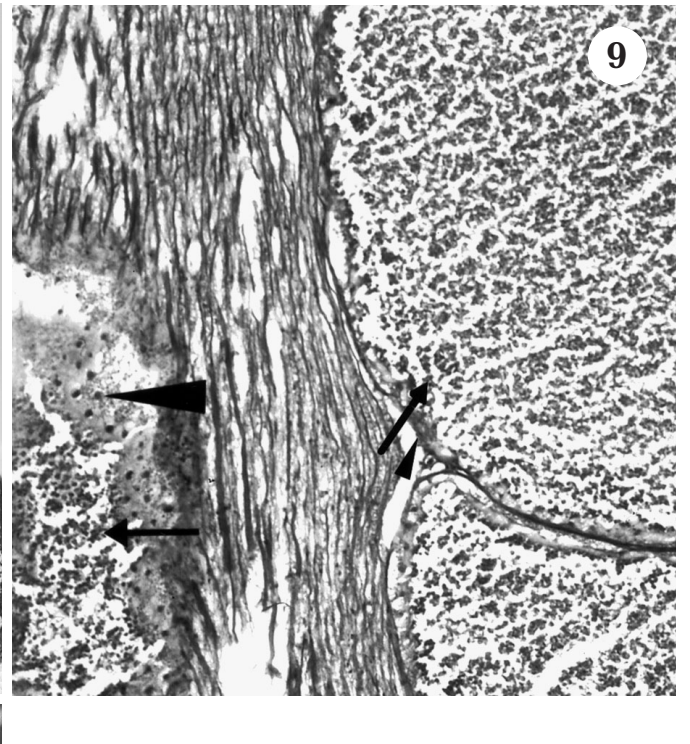

Figs. 8 to 10. Lutjanus erythropterus infected by Kudoa lutjanus. Fig. 8. Brain of red snapper. Two aggregated pseudocysts on the surface of the brain tissues $(\mathrm{N})$ and one (large arrowhead) in the internervous tissues. Spores (arrow) in the pseudocysts are shown on the surface and in the internervous tissues (large arrowhead) of the brain; the parasites and host tissue are separated by a thin hyaline wall (small arrowhead), with no inflammatory reaction or internervous tissues $(H \& E, \times 200)$. Fig. 9. Magnification of Fig. 8. Spore (arrows) release from the pseudocyst (small arrowhead), the inflammatory exudative fluid and the inflammatory cells (large arrowhead) are shown in the internervous tissues $(\mathrm{H} \& \mathrm{E}, \times 400)$. Fig. 10. Magnification of Fig. 9. Mature spores found in the pseudocyst. Longitudinal section though 2 polar capsules (arrows) and 4 polar capsules in cross section (arrowhead) (H\&E, $\times 1000)$

Aggregated pseudocysts also appeared in the brain, swim bladder and eye; the presence and intensity of the pseudocyst lesions in various organs of the red snapper are illustrated in Table 1. Higher numbers of pseudocysts were present in the brain than in the other organs of red snapper.

The only 4 Kudoa species identified in the brain tissue of fish in earlier studies were $K$. cerebralis from the striped bass Morone saxatilis (Paperna \& Zwerner 1974), K. tetraspora from the mullet Mugil cephalus (Narasimhamurti \& Kalavati 1979), Kudoa sp. from the barramundi perch Lates calcarifer (Langdon 1990) and $K$. paralichthys $\mathrm{n}$. sp. from the olive flounder Paralichthys olivaceus (Cho \& Kim 2003). Spore measurements were comparable to those described from other hosts by previous authors (Paperna \& Zwerner 1974, Narasimhamurti \& Kalavati 1979). Paperna \& Zwerner (1974) recorded $K$. cerebralis spores at $5.5 \mu \mathrm{m}$ in length (range: 4.8 to $5.8 \mu \mathrm{m}$ ) and $7.0 \mu \mathrm{m}$ in 
width (range: 4.8 to $8.6 \mu \mathrm{m}$ ), with a large polar capsule of 3.7 length $(2.6$ to $4.7 \mu \mathrm{m})$ and $1.5 \mu \mathrm{m}$ width (range: 1.0 to $1.8 \mu \mathrm{m}$ ). Naraimhamurti \& Kalavati (1979) gave a range of $9.0 \mu \mathrm{m}$ width, with a polar capsule of $3.6 \mu \mathrm{m}$ length and $2.0 \mu \mathrm{m}$ width. Langdon (1990) documented a range of lengths from 6.5 to $7.0 \mu \mathrm{m}$ and widths from 9.0 to $10.0 \mu \mathrm{m}$, with polar capsules of 3.1 to $3.2 \mu \mathrm{m}$ length and 2.0 to $2.3 \mu \mathrm{m}$ width. Cho \& Kim (2003) gave a length of $5.19 \mu \mathrm{m}$ (range: 4.49 to $5.97 \mu \mathrm{m}$ ) and a width of $8.23 \mu \mathrm{m}$ (range: 7.40 to $8.89 \mu \mathrm{m}$ ), and with a polar capsule of $2.2 \mu \mathrm{m}$ length (range: 1.87 to $2.74 \mu \mathrm{m}$ ) and $1.2 \mu \mathrm{m}$ width (range: 1.0 to $1.42 \mu \mathrm{m}$ ), as shown in Table 2 .

Kudoa lutjanus n. sp. is clearly distinguished from both $K$. tetraspora from the mullet Mugil cephalus (Narasimhamurti \& Kalavati 1979) and Kudoa sp. from the barramundi perch Lates calcarifer (Langdon 1990) by the smaller spore sizes (Table 2). K. lutjanus n. sp. is also clearly differentiated from $K$. cerebralis and $K$. paralichthys n. sp. by the dissimilarity in ratios between the length and width of polar capsules. $K$. lutjanus n. sp. evidently has shorter polar capsules compared to $K$. paralichthys n. sp., although it has longer polar capsules than $K$. cerebralis (Table 2).

Kudoa remains concealed from the immune system of the fish until it breaks the sarcolemma of the muscle fiber, producing a swift inflammatory reaction (Morado \& Sparks 1986). Macrophage infiltration or encapsulation of diseased muscle fibers, or both, have been noted in bocaccio (Whitaker et al. 1996), Pacific whiting (Stehr \& Whitaker 1986) and mahi mahi Coryphaena hippurus L. (Langdon et al. 1992).

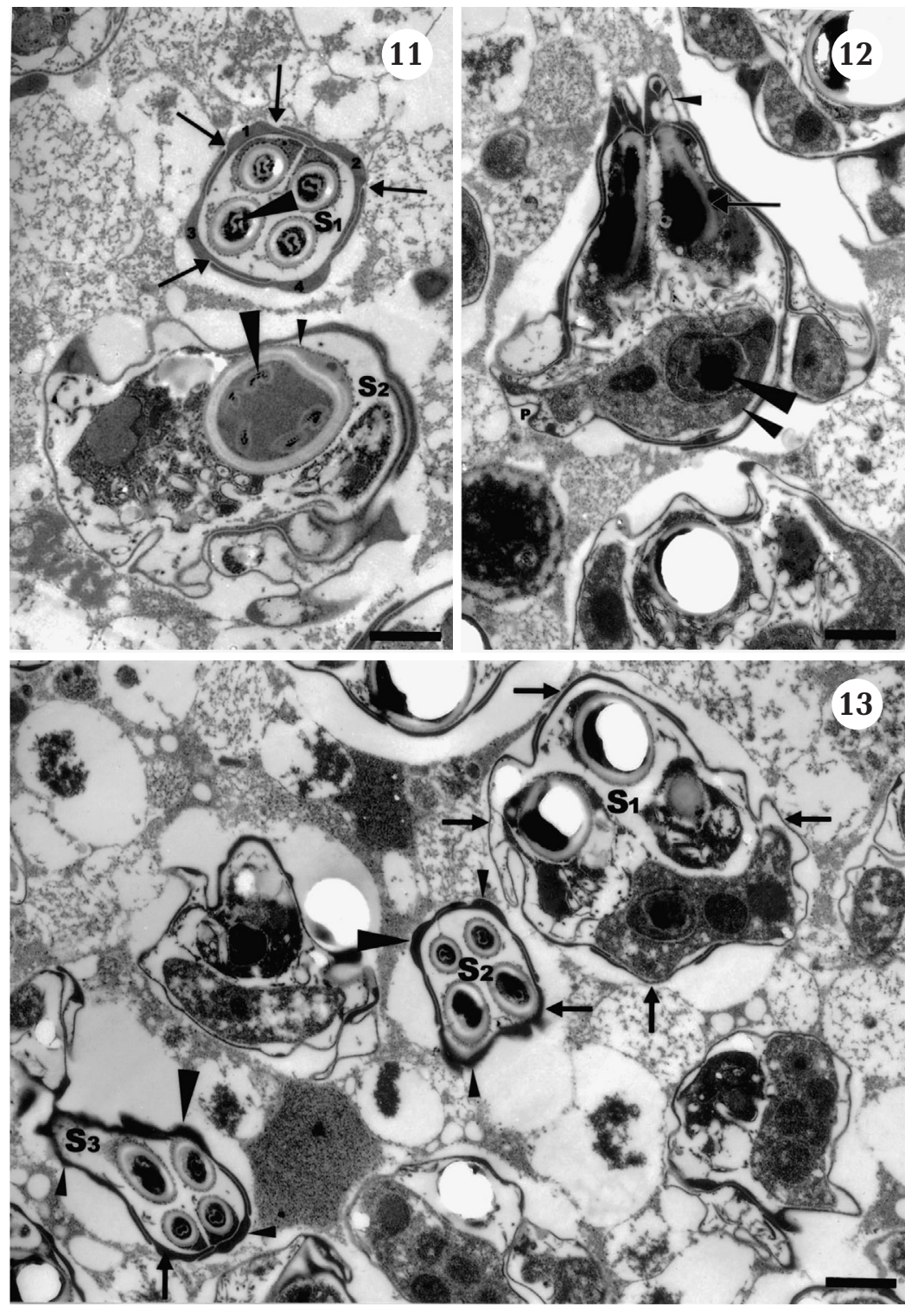

Figs. 11 to 13. Kudoa lutjanus n. sp. Fig. 11. K. lutjanus n. sp. from the brain of Lutjanus erythropterus. Ultrastructure of mature spore stages. Spore $\left(\mathrm{S}_{1}\right)$ shows 1 or 4 polar capsules (arrowhead) in cross sections, with sutures (arrows) between the 4 shell valves. Spore $\left(\mathrm{S}_{2}\right)$ displays 2 to 3 polar filaments (large arrowhead). In mature spores $\left(\mathrm{S}_{1}\right)$, the junctions of 4 shell valves (arrows) reveal that both extremities of the first shell valve were always located in the inner layer of the junction area; in the case of the second and third shell valves, 1 extremity of each shell valve is located at the inner layer in the junction area and the other is in the outer layer; both ends of the fourth shell valve are always positioned in the outer layer of the junction area. Scale bar $=1.5 \mu \mathrm{m}$. Fig. 12. Ultrastructure of mature spore stages. Longitudinal section though 2 polar capsules (arrow) and the apical extensions (small arrowhead); the capsulogenic cells have polar capsules; the sporoplasm (medium-sized arrowhead) consists of an inner spherical cell with a densely granular cytoplasm (large arrowhead). Scale bar $=2 \mu \mathrm{m}$. Fig. 13. Ultrastructure of mature spore stages, cross sections of 3 mature spores $\left(\mathrm{S}_{1}, \mathrm{~S}_{2}\right.$ and $\left.\mathrm{S}_{3}\right)$ though 2 or 4 polar capsules. In mature spore $\left(\mathrm{S}_{1}\right)$, the junction pattern of 4 shell valves (arrows) reveals that both extremities (anterior and posterior) of each shell valve follow a regular organization type in which 1 extremity of each shell valve is located in the inner layer of the junction area and the other is in the outer layer of the junction area. The mature spores $S_{2}$ and $\mathrm{S}_{3}$ have a different junction pattern; both extremities of the first shell valve (arrow) are always located in the inner layer of the junction area, in the second and third shell valves (small arrowheads), 1 extremity of each shell valve is located in the inner layer of the junction area and the other is in the outer layer, both extremities of the fourth shell valve (large arrowhead) are always located in the outer layer of the junction area. Scale bar $=2 \mu \mathrm{m}$ 


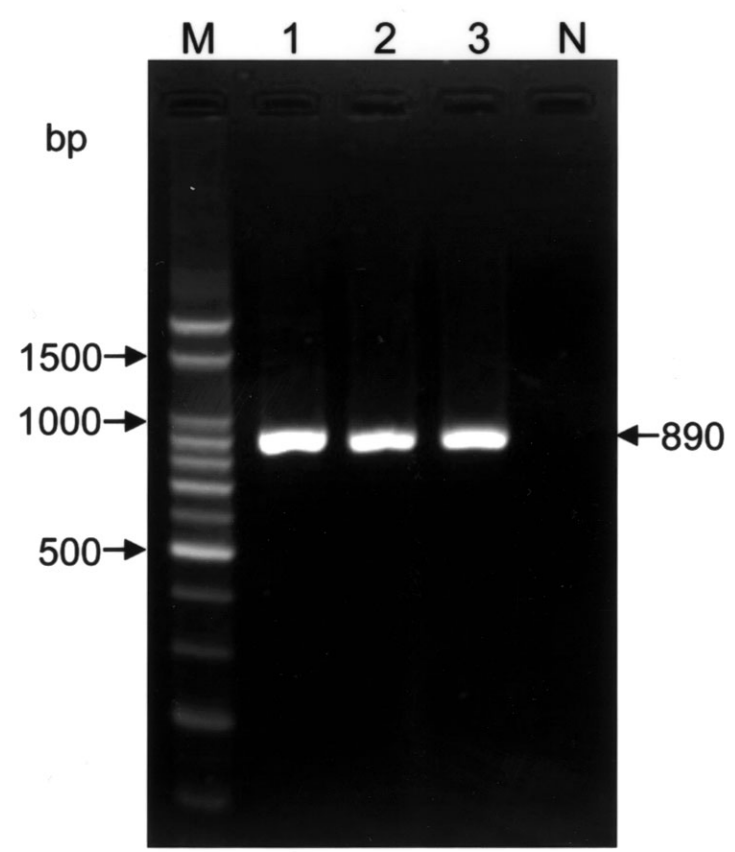

Fig. 14. Kudoa sp. Specificity of Kudoa sp. through PCR assay. Agarose gel $(2 \%)$ of PCR products from $K$. lutjanus n. sp. DNA templates stained with ethidium bromide. Lane M: DNA molecular-weight marker; Lane 1: AOD93020B, Lane 2: AOD93028M; Lane 3: AOD93028B; Lane N: negative control

Infected muscle fibers in Pacific whiting are encompassed by a fibroblast layer and destroyed (Stehr \& Whitaker 1986). Ruptured pseudocysts of free spores in bocaccio, perch and mahi mahi can result in a focal inflammatory response (Langdon et al. 1992, Whitaker et al. 1996). In contrast, little cellular infiltration has been observed in Atlantic salmon (Harrell \& Scott 1985, Whitaker et al. 1994). Cellular response is present in Australian clupeoids (Langdon et al. 1992). In both Atlantic salmon and Australian clupeoides, pseudocysts can totally invade muscle fibers, rupture, then release spores within the interstitium. No host response has been documented histologically in tubesnout, although spores frequently and completely invade myocytes, even breaching the sarcolemma. Whether or not a particular host can produce an inflammatory response toward $K$. thyrsites evidently differs between species (Langdon et al. 1992). In the present study, the authors found that there was a mild inflammatory reaction to some pseudocysts, while others displayed no tissue reaction.

Previous studies and the present research have shown that species of Kudoa with spores that seem similar at the light microscopy level can be further differentiated by means of electron microscopy to visualize their surface and internal ultrastructure. However, even with such a technique, some spores may still seem extremely similar (such as those of $K$. cerebralis and $K$. paralichthys n. sp.). In this investigation, $K$. lutjanus n. sp. is clearly distinguished from K. lunata (Lom \& Dykova 1988) and K. paralichthys (Cho \& Kim 2003) by the junction pattern of shell valves (Fig. 13). Lom \& Dykova (1988) noted that the junction of the shell valve of $K$. lunata was oblique. In $K$. paralichthys, the junctions of shell valves were not oblique, but L-shaped (Cho \& Kim 2003).

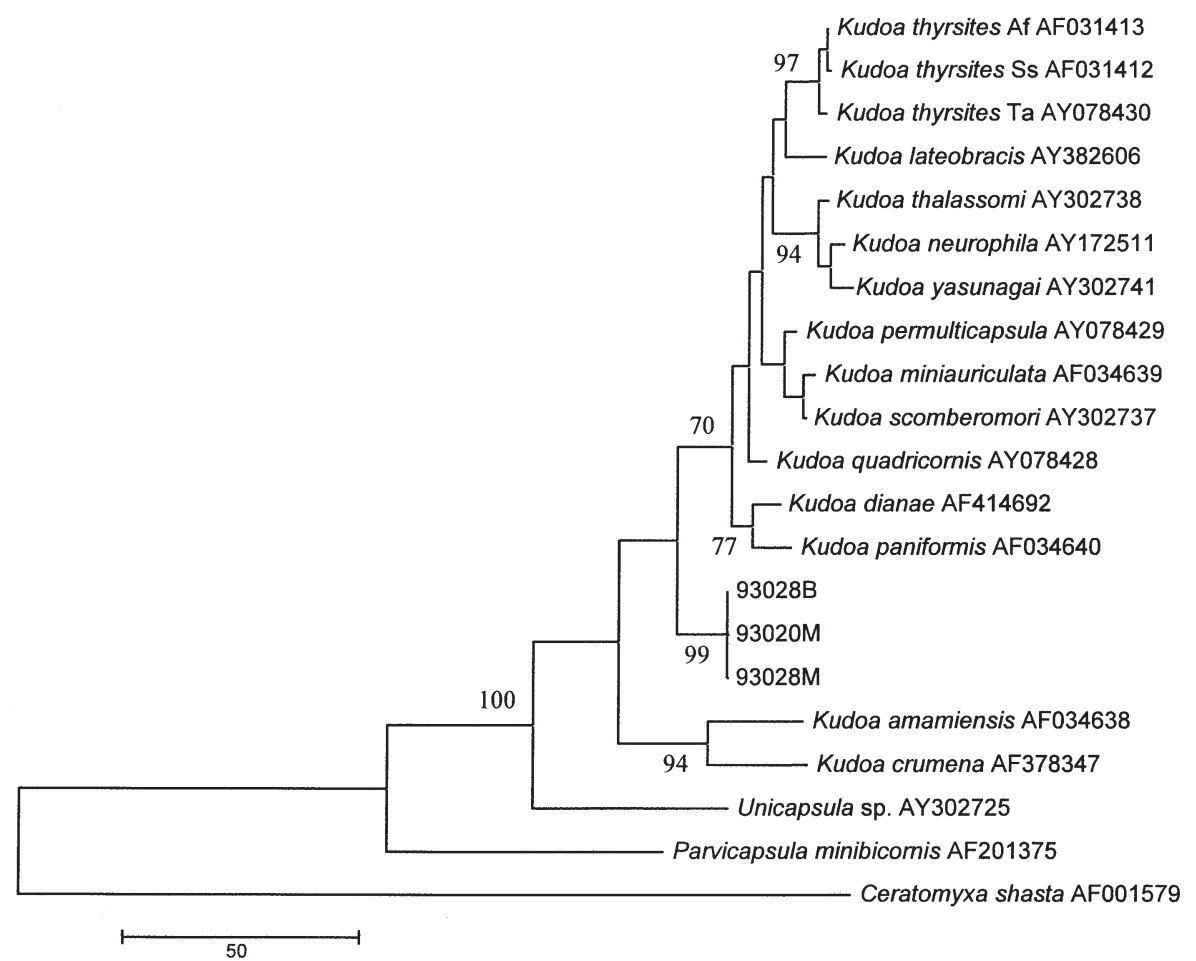

Fig. 15. Maximum-parsimony tree based on 829 unambiguously aligned nucleotide positions; 238 characters were informative, 411 characters were constant and the remaining were parsimony uninformative. The tree shown is 1 of 19 most-parsimonious trees. The numbers at the nodes indicate the levels of bootstrap support based on maximumparsimony analysis of 1000 resampled data sets. The total length of the tree was 614 (gaps and missing data are never used in computing tree lengths). The consistency index (CI) and retention index (RI), excluding uninformative characters, were 0.6089 and 0.6645 , respectively 
The molecular techniques, including partial sequencing of the genomic DNA encoding the SSU rRNA and development of specific PCR tests, have been proven successfully for spores of other Kudoa species (Hervio et al. 1997). Improved characterization and identification of species will provide more accurate host and geographic range records.

Molecular systematics have helped to elucidate relationships with the Myxozoa, but the support for the branches in phylogenetic trees made from this large assemblage of taxa is weak (Kent et al. 2001). However, some general trends are now apparent: (1) marine taxa at the genus level branch earlier than genera that are generally freshwater; (2) taxa cluster more by development at tissue location than by spore morphology; (3) the tetracapsulids branched off early in myxozoan evolution, perhaps reflecting their bryozoan as opposed to their annelid hosts; (4) actinosporean morphology so far offers little information for determining myxosporean counterpart morphology; (5) the unusual marine actinosporeans from Australia appear to form a clade with the marine platysporinids; and (6) the overall lack of generic monophyly may eventually require the more complete accommodation of Myxobolus, Henneguya, some Sphaerospora species. Phylogenetic analysis of the $18 \mathrm{~S}$ rDNA of Myxozoa suggested that the only genus that is clearly monophyletic is Kudoa, which falls out near the base of the tree, with a basically marine clade containing Sinuolinea, Ceratomyxa and Parvicapsula (Kent et al. 2001). ASSU rDNA sequence is now available from some genera of Myxozoa (Hervio et al. 1997, Holzer et al. 2004). Based on the phylogenetic analysis of the SSU rDNA, Whipps et al. (2004) proposed to synonymize Pentacapsla, Hexacapsula and Septemcapsula with Kudoidae and alter the diagnosis of Kudoa to accommodate all marine myxozoan parasites having 4 or more shell valves and polar capsules.

In the present study, phylogenetic analysis of these data has been extended to suggest that the members of Pentacapsla, Hexacapsula and Septemcapsula root within a clade of Kudoa species within the Unicapsula, as an outlier to these genera (Whipps et al. 2004). In this investigation, 3 strains of $K$. lutjanus n. sp. from the red snapper were $100 \%$ identical. The $18 \mathrm{~S}$ rDNA gene sequence data of $K$. lutjanus n. sp. indicate that it is distinct from previously studied Kudoa species, whereas K. quadricornis (GenBank Accession No. AY078428) was 95\% identical with these species. $K$. lutjanus n. sp. branched independently from the Kudoa species, and other genera, Parvicapsula and Ceratomyxa, clustered together. Based on host species, site of infection, geographic location, spore dimensions, ultrastructure of spores, polymerase chain reaction assay, sequencing of SSU rDNA, phylogenetic analysis, the myxosporean examined here is a new species of the genus Kudoa, described as K. lutjanus. Based on this research with freshwater myxosporeans, it appears that many, if not all, myxosporeans need an annelid as an alternate host to fulfill their life cycles (Kent et al. 1994). Therefore, in ongoing work, the authors will use PCR tests for K. lutjanus n. sp. in order to screen invertebrates from pond sediment and from plankton samples, while attempting to discover the alternate invertebrate host and the infectious stage of the parasite for red snapper in a brackish cultured pond.

Acknowledgements. This study was supported by the Council of Agriculture, Taiwan (Grants COA-93-1.8.1. B1[6]).

\section{LITERATURE CITED}

Cho JB, Kim KH (2003) Light- and electron-microscope description of Kudoa paralichthys n. sp. (Myxozoa, Myxosporea) from the brain of cultured olive flounder Paralichthys olivaceus in Korea. Dis Aquat Org 55:59-63

Felsenstein J (1985) Confidence limits on phylogenies: an approach using the bootstrap. Evolution 39:783-791

Fitch WM (1972) Towards defining the course of evolution: minimum change for a specific tree topology. Syst Zool 20: 406-416

Harrell LW, Scott TM (1985) Kudoa thyrsitis (Gilchrist) (Myxosporea: Multivalvulida) in Atlantic salmon, Salmo salar L. J Fish Dis 8:329-332

Hervio DML, Kent ML, Khattra J, Sakanari J, Yokoyama H, Devlin RH (1997) Taxonomy of Kudoa species (Myxosporea), using a small-subunit ribosomal DNA sequence. Can J Zool 75:2112-2119

Holzer AS, Sommerville C, Wootten R (2004) Molecular relationships and phylogeny in a community of myxosporeans and actinosporeans based on their 18S rDNA sequences. Int J Parasitol 34:1099-1111

Jukes TH, Cantor CR (1969) Evolution of protein molecules. In: Munro HN (ed) Mammalian protein metabolism. Academic Press, New York, p 21-132

Kabata Z, Whitaker DJ (1989) Kudoa thyrsites (Gilchrist, 1924) (Myxozoa) in the cardiac muscle of Pacific salmon (Oncorhynchus spp.)and steelhead trout (Salmo gairdneri). Can J Zool 67:341-342

Kent ML, Margolis L, Corliss JO (1994) The demise of a class of protists: taxonomic and nomenclatural revisions proposed for the protist phylum Myxozoa Grasse, 1970. Can J Zool 72:932-937

Kent ML, Andree KB, Bartholomew JL, El-Matbouli M and 12 others (2001) Recent advances in our knowledge of the Myxozoa. J Eukaryot Microbiol 48:395-413

Kudo R (1966) Protozoology, 5th edn. CC Thomas, Springfield, IL

Kumar S, Tamura K, Jakobsen IB, Nei M (2001) MEGA2: molecular evolutionary genetics analysis software. Bioinformatics 17:1244-1245

Langdon JS (1990) Observations on new Myxobolus species and Kudoa species infecting the nervous system of Australian fishes. J Appl Ichthyol 6:107-116

Langdon JS (1991) Myoliquefaction postmortem (milky flesh) due to Kudoa thyrsites (Gilchrist) (Myxosporea: Multivalvulida) in mahi mahi, Coryphaena hippurus L. J Fish Dis 14:45-54 
Langdon JS, Thorne T, Fletcher WJ (1992) Reservoir hosts and new clupeoid host records for the myoliquefactive myxosporean parasites Kudoa thysites (Gilchrist). J Fish Dis 15:459-471

Lom J, Dyková I (1988) Sporogenesis and spore structure in Kudoa lunata (Myxosporea, Multivalvulida). Parasitol Res 74:521-530

Lom J, Dyková I (1992) Protozoan parasites of fishes. Elsevier Science Publishers, Amsterdam

Morado JF, Spark A (1986) Observations on the host-parasite relations of the pacific whiting, Merluccius productus (Ayres), and two myxosporean parasites, Kudoa thysitis (Gilchrist, 1924) and K. paniformis Kabata \& Whitaker, 1981. J Fish Dis 9:445-455

Moran JDW, Kent ML (1999) Kudoa thyrsites (Myxozoa: Myxosporea) Infections in pen-reared Atlantic salmon in the eastern North Pacific Ocean, with a survey of potential nonsalmonid reservoir hosts. J Aquat Anim Health 11: 101-109

Moran JD, Margolis L, Webster JM, Kent ML (1999a) Development of Kudoa thyrsites (Myxozoa: Myxosporea) in netpen-reared Atlantic salmon determined by light microscopy and a polymerase chain reaction test. Dis Aquat Org 37:185-193

Moran JDW, Whitalker DJ, Kent ML (1999b) A review of the myxosporean genus Kudoa Meglitsch, 1947, and its impact on the international aquaculture industry and commercial fisheries. Aquaculture 172:163-196

Narasimhamurti CC, Kalavati C (1979) Kudoa tetraspora n. sp. (Myxosporidea: Protozoa) parasitic in the brain tissue of Mugil cephalus. Proc Indian Acad Sci 88B:85-89

Pampoulie C, Marques A, Rosecchi E, Crivelli AJ, Bouchereau JL (1999) A new myxosporean parasite, Kudoa camarguensis n. sp., recorded on two goby species (Teleostei: Pisces) in the Rhône Delta (Mediterranean Sea, France). J Eukaryot Microbiol 46:304-310

Paperna I, Zwerner DE (1974) Kudoa cerebralis sp. n. (Myxosporidea, Chloromyxidae) from the striped bass, Morone saxatilis (Walbaum). J Protozool 21:15-19

Editorial responsibility: Wolfgang Körting,

Hannover, Germany
Patashnik M, Groninger HS (1964) Observations on the milky condition in some Pacific coast fishes. J Fish Res Board Can 21:335-346

Rzhetsky A, Nei M (1993) Theoretical foundation of the minimum-evolution method of phylogenetic inference. Mol Biol Evol 10:1073-1095

Saitou N, Nei M (1987) The neighbor-joining method: a new method for reconstructing phylogenetic trees. Mol Biol Evol 4:406-425

Stehr C, Whitaker DJ (1986) Host-parasite interaction of the myxosporeans Kudoa paniformis Kabata \& Whitaker 1981 and Kudoa thyrsites (Gilchrist 1924) in the muscle of Pacific whiting, Merluccius productus (Ayres): an ultrastructural study. J Fish Dis 9:505-517

Swearer SE, Robertson DR (1999) Life history, pathology, and description of Kudoa ovivora n. sp. (Myxozoa, Myxosporea): an ovarian parasite of Caribbean labroid fishes. J Parasitol 85:337-353

Whipps CM, Adlard RD, Bryant MS, Kent ML (2003) Two unusual myxozoans, Kudoa quadricornis n. sp. (Multivalvulida) from the muscle of goldspotted trevally (Carangoides fulvoguttatus) and Kudoa permulticapsula n. sp. (Multivalvulida) from the muscle of Spanish mackerel (Scomberomorus commerson) from the Great Barrier Reef, Australia. J Parasitol 89:168-173

Whipps CM, Grossel G, Adlard RD, Yokoyama H, Bryant MS, Munday BL, Kent ML (2004) Phylogeny of the Multivalvulidae (Myxozoa: Myxosporea) based on comparative ribosomal DNA sequence analysis. J Parasitol 90:618-622

Whitaker DJ, Kabata Z, Margolis (1994) Myxosporean parasites and their potential impact on the aquaculture industry, with emphasis on Kudoa species. In: Conley DC (ed) Kudoa workshop proceedings; Nanaimo, BC0. Aquaculture Industry Development Report 94-01, British Columbia Ministry of Agriculture, Fisheries \& Food, Victoria, p 2-7

Whitaker DJ, Kent ML, Sakanari JA (1996) Kudoa miniauriculata n. sp. (Myxozoa, Myxosporea) from the musculature of bocaccio (Sebastes paucispinis) from California. J Parasitol 82:312-315

Submitted: September 10, 2004; Accepted: April 6, 2005

Proofs received from author(s): October 14, 2005 